Criminology Explains Police Violence 


\section{CRIMINOLOGY EXPLAINS}

Robert A. Brooks and Jeffrey W. Cohen, Editors

This pedagogically oriented series is designed to provide a concise, targeted overview of criminology theories as applied to specific criminal justice-related subjects. The goal is to bring to life for students the relationships among theory, research, and policy.

I. Criminology Explains Police Violence, by Philip Matthew Stinson, Sr. 


\section{Criminology Explains Police Violence}

Philip Matthew Stinson, Sr.

\section{甲}


University of California Press

Oakland, California

(C) 2020 by Philip Matthew Stinson, Sr.

Cataloging-in-Publication Data is on file at the Library of Congress.

ISBN 978-0-520-30008-8 (cloth : alk. paper)

ISBN 978-0-520-30009-5 (pbk. : alk. paper)

ISBN 978-0-520-97163-9 (ebook)

$\begin{array}{llllllllll}29 & 28 & 27 & 26 & 25 & 24 & 23 & 22 & 21 & 20\end{array}$

I0 $\quad 9 \begin{array}{lllllllll} & 8 & 7 & 6 & 5 & 4 & 3 & 2 & \text { I }\end{array}$ 